\title{
Old English Hula 'Sheds' and Hull, Yorkshire
}

\author{
Andrew Breeze \\ University of Navarra
}

Hull or Kingston-upon-Hull is a port upon the River Hull. With a population of over 300,000 , it is the fourth biggest city in Yorkshire (after Leeds, Sheffield, and Bradford) and the fifteenth biggest in Britain. Yet its name, like those of other English cities (London, Manchester, Leeds, York, Doncaster), has lacked rational explanation until lately. In 2018 the writer proposed that Hull is not (as long asserted) called after the River Hull, supposedly with an obscure pre-English name. The river is instead called after the town, because Hull derives not from some opaque Celtic hydronym but from Old English bula 'sheds, huts'. Hull is thus a greater namesake of (Much) Hoole 'shed(s)' south-west of Preston, Lancashire. ${ }^{1}$ As for the River Hull, its old name may have been Leven 'smooth one', still that of a village near its source. The original account being a summary one, what follows presents the case in detail.

Keywords: Hull; place-names; Old English; Celtic

\section{The historical background}

Hull or Kingston-upon-Hull, famed for links with the anti-slavery movement, aviation, telephones, fishing, and poetry, is a medieval New Town. In a memorable account of its churches, palaces, defences, hospitals, and religious houses, John Leland attributed the place's prosperity to when its mariners began "passing for fisch into Iseland"; Hull thereby gained "the hoole trade of stoke fisch into England" after it had previously been "but a meane fischar toune, and longid as a membre to Hasille [Hessle] village a 2. or 3. mile off,

\footnotetext{
1 A. Breeze, 'The Names of Yorkshire's Rivers', Transactions of the Yorksbire Dialect Society, cxviii/23 (2018), 71-92.

Andrew Breeze, Selim24 (2019): 149-156.

ISSN 1132-631X / DOI https://doi.org/10.17811/selim.24.2019.149-156
} 
upper on Humber". Leland's phrase "meane fischar toune" should be kept in mind. It is fundamental evidence.

Thanks to fish, then, Hull came from nowhere. Documents chart its rise to greatness. In 1440 it was incorporated, becoming legally separate from Yorkshire and a county in its own right, with a mayor and sheriff. ${ }^{3}$ Earlier events were set out by Pevsner. Edward I bought the settlement in 1293 (hence "Kingston" and the crowns on the city's blazon). "Before that it was Wyke, and belonged to Meaux Abbey". The new Kingston soon ousted its rival Ravenser (down towards the North Sea), becoming in the fourteenth century "the foremost English port on the East Coast". ${ }^{4}$ Its prosperity is clear from a sixteenth-century drawing, showing churches and other buildings within its walls, windmills beyond, and ships moored on the River Hull. ${ }^{5}$ Chaucer thus naturally thought of Hull when declaring of his Shipman, "Ther nas noon swich from Hulle to Cartage" (where "Cartage" is Cartagena, Spain).

\section{Older explanations of Hull's name}

After glorification of the city, consideration of its name and that of its river. The Hull flows twenty-three miles from near Great Driffield to its outlet on the Humber. Ekwall, citing a reference of about the year 1000 (concerning a shrine at Beverley) to ea Hull 'river Hull', fatally took it as a "British rivername". ${ }^{7}$ Yet Kenneth Jackson did not think it Celtic at all. Giving the area as settled by the English in the late fifth century (we shall return to this date), he omitted it from his map of such forms. ${ }^{8}$ This did not stop others from taking Hull as a Celtic form. Margaret Gelling, citing a record of about 1080 on amnen Hul(l) 'river Hull', interpreted the form as either a Scandinavian one meaning 'deep one' or 'river which flows in a cut channel', or else as Celtic and with the sense 'muddy one'. More to the point are her comments on the

2 The Itinerary of John Leland: Parts I to III, ed. L. T. Smith (London, 1907), 48.

${ }^{3}$ English Historical Documents 1327-1485, ed. A. R. Myers (London, 1969), 570-572.

4 N. Pevsner, The Buildings of England: Yorkshire: York and the East Riding (Harmondsworth, 1972), 267.

${ }^{5}$ C. Platt, The English Medieval Town (London, 1976), 43.

${ }^{6}$ G. Chaucer, The Canterbury Tales, ed. J. Mann (Harmondsworth, 2004), 18.

${ }^{7}$ E. Ekwall, The Concise Oxford Dictionary of English Place-Names (Oxford, 1936), 244.

${ }^{8}$ K. H. Jackson, Language and History in Early Britain (Edinburgh, 1953), 208, 220. 
settlement as Wyke (later Southwyke) 'hamlet, village' until it became Kingston in the 1290s, under Edward I. ${ }^{9}$

There is full discussion of the Old English text first mentioning the Hull. ${ }^{10}$ The document being otherwise devoid of Viking influence, John Field naturally doubted that Hull was Scandinavian, and preferred a supposed Celtic root bul- 'muddy. ${ }^{11} \mathrm{He}$ was echoed by Adrian Room. ${ }^{12}$ Neither Field nor Room knew that there is no Celtic root bul- meaning 'muddy' or anything else. It was still given by A. D. Mills, as also the Scandinavian etymology signifying 'deep one'. ${ }^{13}$ For this view taken to an extreme, we turn to the English Place-Name Society's dictionary, wherein a sense 'muddy (river)' is offered from an otherwise unknown Celtic equivalent of Lithuanian sulá 'birch sap' and Old Prussian sulo 'curdled milk. ${ }^{14}$

\section{A phonetic objection to the above}

We propose to demolish these assertations on Hull. Besides the lack of an equivalent in the Celtic languages, there is an insuperable phonetic problem. It is this. The British language spoken in Roman times had no initial $\langle\mathrm{h}\rangle$. The $<\mathrm{h}>$ at the beginning of words in medieval or modern Welsh (a language deriving from British, just as French and Spanish derive from Latin) comes from development of an original initial <s>. The River Severn offers an example. The Romans called it Sabrina, the Welsh now call it Hafren (where the sense is seemingly that of the 'boiling together' of the river's bore or tidal flood). Now, Kenneth Jackson long ago took the development of initial $<$ s $>$ to $<\mathrm{h}>$ in British dialects as occurring by "the middle or later part of the sixth

\footnotetext{
9 M. Gelling, 'Hull', in The Names of Towns and Cities in Britain, ed. W. F. H. Nicolaisen (London, 1970), 111-112.

${ }^{10}$ D. W. Rollason, 'Lists of Saints' Resting-Places in Anglo-Saxon England', AngloSaxon England, vii (1978), 61-83.

${ }^{11} \mathrm{~J}$. Field, Place-Names of Great Britain and Ireland (Newton Abbot, 1980), 88.

12 A. Room, Dictionary of Place-Names in the British Isles (London, 1988), 179.

${ }^{13}$ D. Mills, A Dictionary of English Place-Names (Oxford, 1991), 197.

${ }^{14}$ The Cambridge Dictionary of English Place-Names, ed. V. Watts (Cambridge, 2004), 322, 348.
} 
century". ${ }^{15}$ He used the identical phrase years later in a simple account of Sabrina and Hafren. ${ }^{16}$ Yet the English occupied the Hull region in the late fifth century. Hull thus cannot have been borrowed from a British form with initial $<$ s $>$. That here invalidates all previous statements.

\section{A new approach from Old English}

So we start again with two radical new premises: that Hull's name is neither Scandinavian nor Celtic nor pre-Celtic, but English, and denoted the settlement, not the river. For ea Hull and amnen Hul(l), we take the sense as 'river of Hull, river at Hull', just as one might call the Aire the 'river at Leeds'. The likely derivation of Hull is hence from Old English bula 'sheds, huts'.

Place-name scholars record bula 'sheds, huts' elsewhere in England. In Lancashire, between Preston and Southport, is the parish of Hoole, with the settlements of Much Hoole and Little Hoole, attested in 1204 as Hull and long since explained from Old English bula 'huts'. ${ }^{17}$ Near Worcestershire's border with Warwickshire is the hamlet of Holberrow Green (SP 0259), attested in 1275 as Holbarewe. It stands along a ridge on the WorcesterRedditch road. The first element will be bulu 'shed', the form meaning 'hovelhill' or 'hill with hovels on or by it. ${ }^{18}$ A roadside position evidently did not enrich its inhabitants. It was a medieval favila or shanty-town.

What this miserable place might look like is brought out by Ancrene Wisse 'Guide for Anchoresses', the prose masterpiece of an unknown thirteenthcentury friar from Herefordshire or Shropshire. He cited the Scriptural direction to one who is "fairest among women" to feed her "kids beside the shepherds' tents" (Song of Solomon 1:7). The last phrase he rendered as bi beordmonne bulen of ris of of leaues. ${ }^{19}$ This is regularly mistranslated "beside the

15 K. H. Jackson, 'The British Language During the Period of the English Settlements', in Studies in Early British History. ed. N. K. Chadwick (Cambridge, 1954), 61-82.

${ }^{16}$ K. H. Jackson, 'The British Languages and Their Evolution', in The Mediaeval World. ed. D. Daiches \& A. Thorlby (London, 1973), 113-126.

17 E. Ekwall, The Place-Names of Lancashire (Manchester, 1922), 137.

18 A. Mawer \& F. M. Stenton, The Place-Names of Worcestershire (Cambridge, 1927), 327.

${ }^{19}$ The English Text of the Ancrene Riwle, ed. M. Day (London, 1952), 43. 
herdsmen's tents of boughs and leaves". ${ }^{20}$ Tents are made of cloth, however, not "boughs and leaves". The sense of bulen is 'shelters', made of whatever came to hand.

Returning to toponyms, we can add two more, leaving to one side Holcot (north of Northampton) and Hulcott (north-east of Aylesbury), where the first element may mean 'hollow' and not 'shed'. The first is the Cheshire hamlet (absent from modern maps) of Hull 'huts, sheds' (Hulle in 1283), near Appleton, south of Warrington. ${ }^{21}$ Second is a Gloucestershire field called Hull Piece 'land containing a shed' (from Old English bulu), near Poulton, in the flat lands between Cirencester and Fairford. ${ }^{22}$ Toponyms from Lancashire, Worcestershire, Cheshire, and Gloucestershire thus confirm interpretation of Yorkshire's Hull as from Old English bula 'sheds, huts'. Any other meaning is out of the question.

\section{Conclusions}

If the above process of thought is coherent, it offers four conclusions. First, in Yorkshire, Hull will originally have meant the settlement, not the river. Second, the form will be an English one meaning virtually the same as Wyke 'hamlet, village' already noted. It resembles too the names of Dairycoates, Sculcoates, and Southcoates, with second elements meaning 'cottages, shelters' (and 'Scul' being the Scandinavian personal name Skúli) and all now within Hull's industrial fringe. ${ }^{23}$

Third, the links set out by professional scholars over the years for expressions in Latvian or Lithuanian and so on can be dismissed. When Leland spoke of Hull as once "a meane fischar toune", analysis of Hull shows him as to the point, for bula need mean little more than 'hovels'. A great city had humble beginnings. It is not alone. Even though Droitwich means 'dirty salt-works' and Swindon 'pig hill', nobody thinks the worse of them for that.

Present analysis hence clarifies Hull's beginnings, as well as demonstrating entrenched error in the scholarly community. There is a fourth and final point. If

\footnotetext{
${ }^{20}$ The Ancrene Riwle, tr. M. B. Salu (London, 1955), 43.

21 E. Ekwall, The Concise Oxford Dictionary of English Place-Names, 4th ed. (Oxford, 1960), 256.

${ }^{22}$ J. Field, English Field-Names (London, 1972), 110.

${ }^{23}$ P. H. Reaney, The Origin of English Place-Names (London, 1960), 35-37.
} 
Hull is not Celtic, can we point to toponyms near Hull which are? The answer is yes. There are four instances, two of them from Bede's History. The names are In Dera Uuda, Leven, Roos, Wawne. The first and last should interest both archaeologists and historians, for they indicate the sites of Northumbrian monasteries, one of them hitherto unknown.

(a) In Dera Uuda 'in (the) wood of the Deirans'.

This is the name of a monastery at what is now Beverley ('beaver stream'), mentioned in book five of Bede's History. It is agreed that Deirans, by which the Anglians of the Yorkshire region knew themselves, is a Celtic expression, and that the first sense was that of a people ('Deirans'), not a territory ('Deira'). Nor has it anything to do with early Welsh $d w f r$ 'water'. It relates instead to Welsh dewr (earlier deur) 'brave, courageous'. The Deirans had a military aristocracy who gave themselves out as "heroes, valiant ones". ${ }^{24}$ They resembled the Bernicians, whose fighting men stormed the gap in an enemy battle-line (compare Irish bearna 'battle-gap'), or warriors in the British kingdom of Elmet east of Leeds, where the sense is 'those who cut down many (in combat)', as shown by Welsh $e l$ - 'many' and medi 'reap, harvest; cut down (foes in conflict)'.

(b) Leven, Roos, Wawne. ${ }^{25}$

These all refer to villages and are dealt with together.

(i) Roos 'moor', not far from the sea at Withernsea, is equivalent to Welsh rbos 'heathland'. The region, one of glacial boulder clay and infertile soil, was unattractive to settlers. British communities must have survived here long enough for the form to be borrowed by English.

(ii) Leven is north-east of Beverley, by the headwaters of the Hull in an area of drained marshland. Although it is accepted that the name was that of a stream, the sense has been disputed. Analogies in Welsh yet allow an answer. Welsh llyfn (feminine llefn) 'smooth' and so 'smoothly-flowing one' is applied

\footnotetext{
24 A. Breeze, 'The Origin of the Name Deira', Transactions of the Yorksbire Dialect Society, xix/97 (1997), 35-39.

${ }^{25}$ R. Coates \& A. Breeze, Celtic Voices, English Places (Stamford, 2000), 342.
} 
to several rivers in Wales, as at Llanllyfni on the western edge of Snowdonia. ${ }^{26}$ This provides a likely sense for the sluggish waters of the Hull and its tributaries, as a connection with Welsh llwyf'elm-trees' does not. There is also an implication that Leven was the former British name of the Hull. Surviving unrecognized until now at a settlement on its upper reaches, it has (it seems) been displaced as a hydronym by Hull.

(iii) Wawne, five miles north of the centre of Hull (and two miles south of vanished Meaux Abbey). Professor Richard Coates perceived the form as Celtic and equivalent to Welsh gwaun 'moor, meadow' (the $<\mathrm{g}>$ appearing in the late eighth century, and thus being irrelevant to Yorkshire). We may go further. In book three of his history, Bede tells of Bishop Tuda, who died in 664 and was buried at the monastery of 'Paegnalaech', routinely misunderstood by Michael Lapidge and other editors of Bede, who then cannot locate it. There is again a simple solution. The correct initial is not $\langle\mathrm{p}\rangle$. It is the similar Anglo-Saxon runic letter wynn, with the value $/ \mathrm{u} /$ or $/ \mathrm{w} /$, so that we read 'Uaegnalaech'. The toponym is a hybrid, with a British element meaning 'meadow' and an English one meaning 'stream'. ${ }^{27}$ It enables the identification of Wawne as the site of a monastery mentioned by Bede, once again underlining the importance of place-names for researchers on Yorkshire's early history and archaeology. On that may now be noted observations from the Humber Wetlands Survey, that "large tracts of the Holderness Plain, Hull Valley, and the southern Vale of York were regularly flooded from the fifth to ninth centuries"; the result was "low levels of exploitation in these areas, except for meadowland" with "attendant settlement" on "free-draining soils nearby". ${ }^{28}$

\footnotetext{
${ }^{26}$ H. W. Owen \& R. Morgan, Dictionary of the Place-Names of Wales (Llandysul, 2007), 270-271.

${ }^{27}$ A. Breeze, 'The Cult of St Tuda and Wawne, East Riding', Northern History, xlviii (2011), 145-146.

${ }^{28}$ J. D. Richards \& J. Naylor, 'Settlement, Landscape, and Economy', in Early Medieval Northumbria, ed. D. Petts \& S. Turner (Turnhout, 2011), 129-149.
} 
156 Andrew Breeze

\section{Author's address}

Departamento de Filología, Lenguas Modernas

Universidad de Navarra

Campus Universitario, $\mathrm{s} / \mathrm{n}$

31009 Pamplona, Spain

e-mail: abreeze@unav.es received: 10 April 2019

revised version accepted: 20 May 2019 